\title{
Ethylene and abscisic acid in the control of development of the rhizome of Kohleria eriantha (Benth.) Hanst. (Gesneriaceae)
}

\author{
Julieta Andrea Silva de Almeida ${ }^{1 *}$, Concetta Kascheres ${ }^{2}$ and Maria de Fátima D.A. Pereira ${ }^{3}$ \\ ${ }^{1}$ Centro de Café "Alcides Carvalho”, Instituto Agronômico de Campinas, CP28, 13001-970, Campinas, SP, Brasil; ${ }^{2}$ Departamento de \\ Química, Orgânica, Instituto de Química, CP6154, Universidade Estadual de Campinas, 13083-970, Campinas, SP, Brasil; ${ }^{3}$ Departamento \\ de Fisiologia Vegetal, Instituto de Biologia, CP6109, Universidade Estadual de Campinas, 13083-970, Campinas, SP, Brasil; Corresponding \\ author:julietasa@iac.sp.gov.br
}

Received: 24/06//2005; Accepted: 15/12/2005

Kohleria eriantha has rhizomes which are underground stems with buds enclosed by modified leaves, that store starch. The buds of this rhizome can develop in two morphological patterns: an aerial shoot (similar to the mother plant) or a rhizome, depending on the water level present in the substrate. Development of the shoot was inhibited by low water availability $(1 \mathrm{~mL})$ in the substrate. It was verified that ethylene and ABA were involved in controlling the development of the rhizome pattern under low water availability. Treatments with ethrel, PEG and ABA induced shoot development whereas treatments with $\mathrm{AgNO}_{3}$ or AVG inhibited shoot development. Increased ethylene and ABA were observed under conditions that inhibited shoot development. Moreover, it is suggested that ABA may induce the production of ethylene in the sections of the rhizome under low water availability.

Key words: abscisic acid, buds, ethylene, meristem, rhizome.

Etileno e ácido abscisico no controle do desenvolimento do rizoma de Kohleria eriantha (Benth.) (Gesneriaceae): Kohleria eriantha possui rizomas subterrâneos, caule com gemas envoltas por folhas modificadas que armazenam amido. As gemas desse rizoma podem-se desenvolver em dois padrões morfológicos: o padrão parte aérea (semelhante à planta mãe) ou um rizoma dependendo do nível de água do substrato. O desenvolvimento do padrão parte aérea foi inibido pela baixa disponibilidade de água do substrato $(1 \mathrm{~mL})$. Verificou-se que o etileno e o ABA estavam envolvidos com o controle do desenvolvimento do padrão rizoma na ausência ou baixa disponibilidade hídrica. Tratamentos com ethrel, PEG e ABA induziram o desenvolvimento do padrão parte aérea, enquanto os tratamentos com $\mathrm{AVG}$ e $\mathrm{AgNO}_{3}$ inibiram o desenvolvimento do padrão parte aérea. Observaram-se aumento de etileno e ABA sob condições que inibiram o desenvolvimento da parte aérea. Sugere-se, também, que $\mathrm{ABA}$ pode induzir a produção de etileno em seções do rizoma na ausência ou em baixa disponibilidade hídrica.

Palavras-chave: ácido abscísico, etileno, gemas, meristema, rizoma.

\section{INTRODUCTION}

Kohleria eriantha belongs to the family Gesneriaceae and is distributed from southern Mexico down to Peru and Suriname, with its center of diversity in the Colombian highlands. This species produces rhizomes which are underground stems (growing perpendicular to the surface of the ground) that have buds enclosed by modified leaves. These organs store starch (Almeida, 1997; Almeida and
Pereira, 2000) and the buds are capable of producing either aerial shoots or additional rhizomes. These organs are known to be an adaptation that aids in survival during the dry season (Anonymous, 1991; Kvist and Skog, 1992).

The development of these buds into rhizomes instead of aerial shoots is a response to low or the lack of water availability (1 mL) (Almeida and Pereira, 2004). Water availability is known to influence $\mathrm{ABA}$ responses, and $\mathrm{ABA}$ is known to 
influence ethylene responses (Cracker and Abeles, 1969; Jackson and Osborne, 1975; Goren et al., 1979; Yeh et al., 1995). These observations led to the hypothesis that these growth substances might be involved in the control of development of the rhizome of $K$. eriantha under low water availability.

Low water availability has been shown to be a factor that triggers ethylene production in plants (Ben-Yehoshua and Aloni, 1974; Apelbaum and Yang, 1981; Kapuya and Hall, 1984; Hale and Orcutt, 1987; Hyodo, 1991). 1aminocyclopropane-1-carboxylic acid (ACC) is the direct precursor of its synthesis (Saftner, 1992; Sarquis et al., 1992; Rothan and Nicolas, 1994). Every plant tissue may produce ethylene (Yu and Yang, 1980; Yang and Hoffman, 1984; Mattoo and White, 1991) but this production may also be indirectly induced by exogenous auxin (Blumenfeld, 1975; Bradford and Yang, 1980; Yoshii and Imaseki, 1981; Yeang and Hillman, 1982; Zimmerman and Wilcoxon, 1935 apud Yang, 1987; Arteca et al., 1988; Smulders et al., 1990; Hoson et al., 1990; Kim et al., 1992).

Endogenous ABA content may also increase in plants exposed to lack of water (Trewavas, 1981; Zhang and Davies, 1987), as verified in Salix viminalis (Barros and Neill, 1987), Craterostigma plantagineum (Bartels et al., 1990), Glycine max (Creelman et al., 1990), Funaria hygrometrica (Werner et al., 1991), Oriza sativa (Grossmann and Kwiatrowski, 1993a), Helianthus annuus (Grossmann et al., 1993b), Solanum tuberosum (Leone et al., 1994) and Fatsia japonica (Lopez Carbonell et al., 1994).

Ethylene and ABA may also influence morphological development in different species (Chopra and Kapur, 1988; Vreugdenhil and van Dijk, 1989a,b; Abeles et al., 1992; Smart et al., 1995). Therefore, the aim of this study was to verify the possible involvement of ethylene or ABA in the control of the developmental pattern of rhizome buds of Kohleria eriantha under the condition of low water availability.

\section{MATERIAL AND METHODS}

Rhizomes of $K$. eriantha were collected from plants cultivated in beds. Rhizomes were divided into $2 \mathrm{~cm}$ long sections, containing six modified leaves and one bud in each. The sections were placed in Petri dishes $(9 \mathrm{~cm}$ diameter) lined with three layers of filter paper, of $6 \mu \mathrm{m}$ porosity, that was moistened with 1 or $12 \mathrm{~mL}$ of water, and stored in polythene bags and kept in a growth chamber at $30^{\circ} \mathrm{C}$, in the light. The condition of $1 \mathrm{~mL}$ was considered as low water availability whereas $12 \mathrm{~mL}$ formed a film of water on the substrate surface and was regarded as high water availability. Rhizome sections were treated with solutions of ethrel, ABA, indole-3-acetic acid (IAA), 6-benzylamino-purine (6-BA), $\mathrm{ACC}$, silver nitrate $\left(\mathrm{AgNO}_{3}\right)$ and aminoethoxyvinylglycine acid (AVG) (table 1). Sections were also kept on substrate with $12 \mathrm{~mL}$ of PEG (Polyethyleneglycol) solution (-6 MPa) prepared according to Michel and Kaufamann (1973), and treated with a droplet $(50 \mu \mathrm{L})$ of $\mathrm{AgNO}_{3}$ at $500 \mathrm{mg} \cdot \mathrm{L}^{-1}$.

Ethylene levels were estimated in rhizome sections on substrate with 1 and $12 \mathrm{~mL}$ of water. Flasks containing rhizomes sections were sealed with septa after a small glass tube containing three $\mathrm{KOH}$ pellets $(0.28 \mathrm{~g})$ had been introduced to reduce the $\mathrm{CO}_{2}$ level (Tan and Thimann, 1989). Gas samples, $1 \mathrm{~mL}$, were collected 24 and $48 \mathrm{~h}$ after the beginning of the experiment, and were injected into a "Varian 2440 " gas chromatograph, equipped with a flame ionization detector and a $6 \times 1 / 4$ in "Pyrex" column. The column solid phase consisted of Poropak $\mathrm{T}$ of $80 / 100$ mesh and $\mathrm{N}_{2}$ was used as the mobile phase. Temperatures for the equipment were: column, $100^{\circ} \mathrm{C}$; injector, $140^{\circ} \mathrm{C}$ and detector $190^{\circ} \mathrm{C}$. Ethylene was quantified by comparison of the heights of the sample and standard peaks.

The extraction of ABA followed the method described by Saunders (1978), with modifications. Extracts of ABA

Table 1. Treatments applied to rhizome sections of $K$. eriantha.

\begin{tabular}{|c|c|c|c|c|}
\hline Substance & Concentration & $\begin{array}{c}\text { Number and interval } \\
\text { of applications: }\end{array}$ & $\begin{array}{c}\text { Solution } \\
\text { volume }(\mu \mathrm{L})\end{array}$ & $\begin{array}{c}\text { Water volume } \\
\text { on substrate }(\mathrm{mL})\end{array}$ \\
\hline Ethrel & $10^{-3} \mathrm{M}$ & 5 - every 2 days & 20 & 12 \\
\hline $\mathrm{ABA}$ & $10^{-3} \mathrm{M}$ & 5 - every 2 days & 25 & 12 \\
\hline $6-\mathrm{BA}$ & $10^{-3} \mathrm{M}$ & 10 - every day & 25 & 1,12 \\
\hline IAA & $10^{-3} \mathrm{M}$ & 10 - every day & 25 & 12 \\
\hline $\mathrm{IAA}+6-\mathrm{BA}$ & $10^{-3} \mathrm{M}$ & 10 - every day & 25 & 1 \\
\hline $\mathrm{ACC}$ & $10^{-3} \mathrm{M}$ & 10 - every day & 20 & 12 \\
\hline $\mathrm{AgNO}_{3}$ & 1,10,50,100, 200, $500 \mathrm{mg} . \mathrm{L}^{-1}$ & 1 - every day & 50 & 1 \\
\hline AVG & $10^{-3} \mathrm{M}$ & 2 - every day & 15 & 1 \\
\hline
\end{tabular}


were obtained from rhizome sections (5 g) kept on substrate with 1 or $12 \mathrm{~mL}$ of water for 10 days. The tissue was macerated in $80 \%$ methanol which was removed under reduced pressure at $35^{\circ} \mathrm{C}$. The remaining aqueous solution was acidified with $1 \mathrm{~N} \mathrm{HCl}$ to $\mathrm{pH} 3$ and partioned three times against $20 \mathrm{~mL}$ ethyl acetate. The organic fraction was obtained and partioned three times against $20 \mathrm{~mL} \mathrm{NaHCO}$ (5\%). The aqueous fraction was acidified to $\mathrm{pH} 3$ with $\mathrm{HCl}$ and extracted three times with an equal volume of ethyl acetate to obtain the acid fraction. To purify the acid fraction, the ethyl acetate was removed under reduced pressure $\left(35^{\circ} \mathrm{C}\right)$, and the residue was resuspended in $2 \mathrm{~mL}$ of methanol. The resulting solution was applied to a sep pak $\mathrm{C} 18$ cartridge and eluated with $8 \mathrm{~mL}$ of methanol. The filtrate was dried under reduced pressure $\left(35^{\circ} \mathrm{C}\right)$ and resuspended in a solution of $1 \mathrm{~mL}$ of methanol and $0.5 \%$ acetic acid $(2: 3 \mathrm{v} / \mathrm{v})$. To separate ABA, the purified extract was subjected to high performance liquid chromatography (HPLC), using a C18 ODS-Hypersil (5 $\mu \mathrm{M}$, $250 \times 5 \mathrm{~mm}$ ) column eluted at a flow rate of $1 \mathrm{~mL} \cdot \mathrm{min}^{-1}$ with a gradient of $0.5 \%$ acetic acid and methanol, increasing from 40 to $85 \%$ methanol over $30 \mathrm{~min}$, and monitored at 260 nm (Jensen et al., 1986, with modifications). Eluates from the acid fractions corresponding to the retention time of the standard ABA isomers were collected, dried under reduced pressure $\left(35^{\circ} \mathrm{C}\right)$ and methylated with $10 \mathrm{~mL}$ of diazomethane solution prepared according to Schlenk and Gellerman (1960). The methylated extract was dried under reduced pressure $\left(35^{\circ} \mathrm{C}\right)$ and resuspended in $500 \mu \mathrm{L}$ of methanol, and then concentrated in nitrogen to $200 \mu \mathrm{L}$. An aliquot of 1 $\mu \mathrm{L}$ from each extract was injected into a gas chromatograph coupled to a mass spectrometer (HP 5988A), using a "HP1 Fused Silica Capillary, $25 \mathrm{~m}$ x $0.2 \mathrm{~mm}$ " column and the same procedure being used for the standard ABA. The chromatographic conditions used were: initial temperature of the oven $50^{\circ} \mathrm{C}$ and final temperature $230^{\circ} \mathrm{C}$, heating rate $30^{\circ} \mathrm{C}$ per minute, injector $230^{\circ} \mathrm{C}$, detector $280^{\circ} \mathrm{C}$, and scan range: 40-400 amu (atomic mass unit).

All the treatments had four replicates, each with ten rhizome sections, except for the quantification of ethylene, where each replicate consisted of seven sections. The experiments were conducted in a factorial type experimental design. The data were subjected to ANOVA, using the "F" test and comparison of means by the Tukey test, both at the $5 \%$ level (Pimentel, 1984).

\section{RESULTS}

Rhizome sections of $K$. eriantha produced additional rhizomes (figure 1A) or developed aerial shoots (figure 1B) when kept on substrate with 1 and $12 \mathrm{~mL}$ of water, respectively. Sections treated with ethrel $\left(10^{-3} \mathrm{M}\right)$ and kept on substrate with $12 \mathrm{~mL}$ of water also developed a high percentage of rhizomes (figure 2A), similar to the response produced by the control on $1 \mathrm{~mL}$ of water. Control sections on $12 \mathrm{~mL}$ of water developed aerial shoots (figure $2 \mathrm{~B}$ ).

In figure 2 it can also be observed that the use of increasing doses of $\mathrm{AgNO}_{3}$ caused a gradual reduction in the development of rhizomes, and favored the formation of aerial shoots. Concentrations of 50, 100, 200 and 500 $\mathrm{mg} . \mathrm{L}^{-1}$ of $\mathrm{AgNO}_{3}$ inhibited the development of additional rhizomes on sections with $1 \mathrm{~mL}$ of water (figure $2 \mathrm{C}$ ). Indeed, $\mathrm{AgNO}_{3}$ treated rhizome buds started to develop aerial shoots to a level similar to that of the control on 12 $\mathrm{mL}$ of water (figure $2 \mathrm{D}$ ).

The use of IAA, 6-BA and IAA + 6-BA, aimed at promoting the production of ethylene indirectly, did not
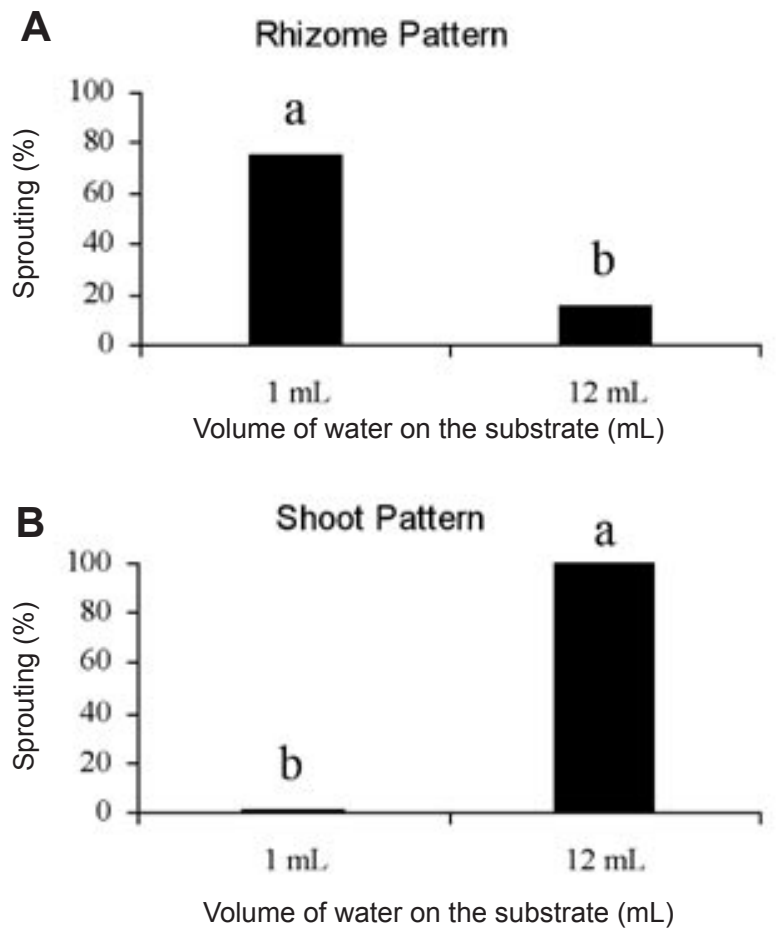

Figure 1. Effect of 1 and $12 \mathrm{~mL}$ of water in the substrate on the pattern of sprouting development of rhizome sections of $K$. eriantha kept under continuous light at $30^{\circ} \mathrm{C}$, on day 20 of the experiment. A: Rizhome pattern; B: Shoot pattern. Different letters in each figure indicate significant differences by the Tukey test at the $5 \%$ level. 
cause any alteration to the morphological structure of the rhizome sections kept on substrate with $12 \mathrm{~mL}$ of water (data not shown). Treatment with ACC $\left(10^{-3} \mathrm{M}\right)$ also did not have any effect on the pattern of development of rhizome sections on substrate with $12 \mathrm{~mL}$ of water (data not shown).

AVG not only inhibited the development of additional rhizomes on sections treated with $1 \mathrm{~mL}$ of water (figure $2 \mathrm{E}$ ), but induced development of aerial shoots (figure $2 \mathrm{~F}$ ). Rhizome sections on substrate to which $12 \mathrm{~mL}$ of PEG (-6 $\mathrm{MPa}$ ) solution was added attained as high a percentage of rhizomes as the control on $1 \mathrm{~mL}$ of water (figure $3 \mathrm{~A}$ ). On the other hand, sections on substrate with $12 \mathrm{~mL}$ of PEG (-6 $\mathrm{MPa}$ ) with the addition of $\mathrm{AgNO}_{3}$ developed aerial shoots (figure $3 \mathrm{~B}$ ). PEG is able to modify the osmotic potential and thus induce plant water deficit.

Rhizome sections on substrate with $12 \mathrm{~mL}$ of water and treated with ABA $\left(10^{-3} \mathrm{M}\right)$ developed a rhizogenous growth pattern, similar to the control on $1 \mathrm{~mL}$ of water (figure $3 \mathrm{C}$ ). However only aerial shoots developed on sections with 12 $\mathrm{mL}$ of water and no ABA (figure 3D).

\section{A}

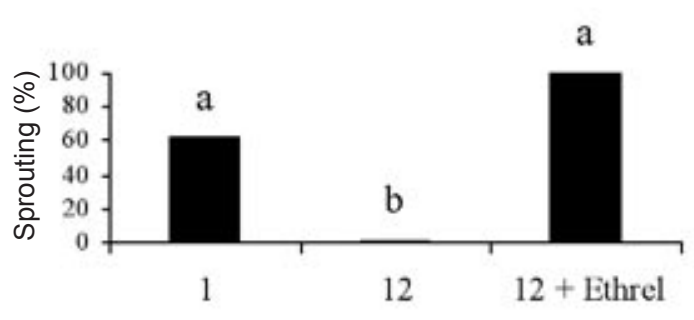

Volume of water on the substrate $(\mathrm{mL})$

C

Rhizome Pattern

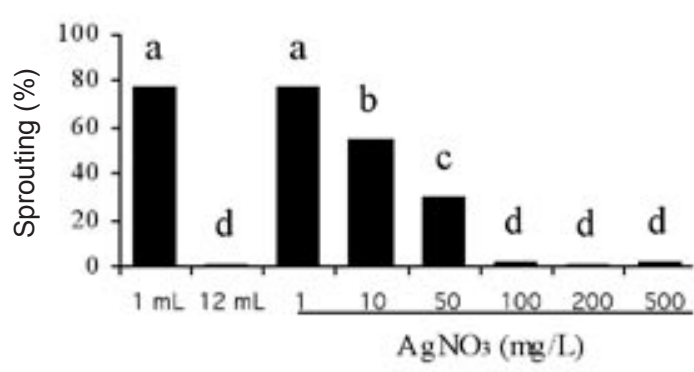

$1 \mathrm{~mL}$ of water on the substrate

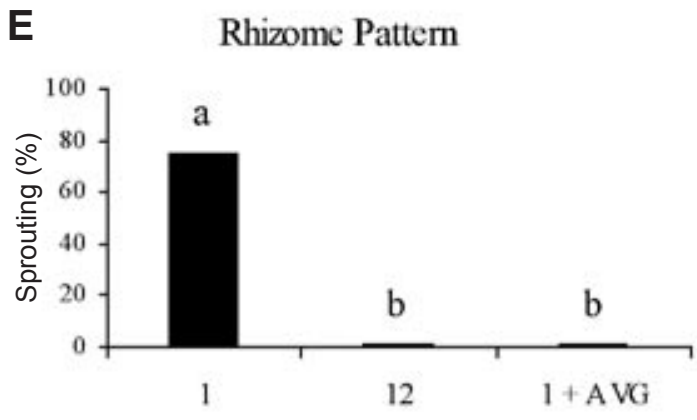

Volume of water on the substrate $(\mathrm{mL})$
B

Shoot Pattem

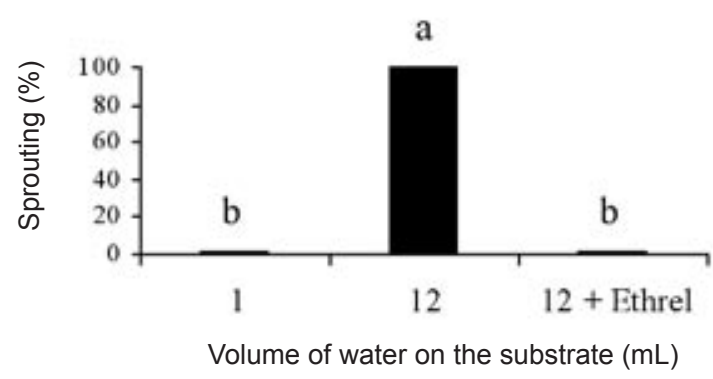

D Shoot Pattem
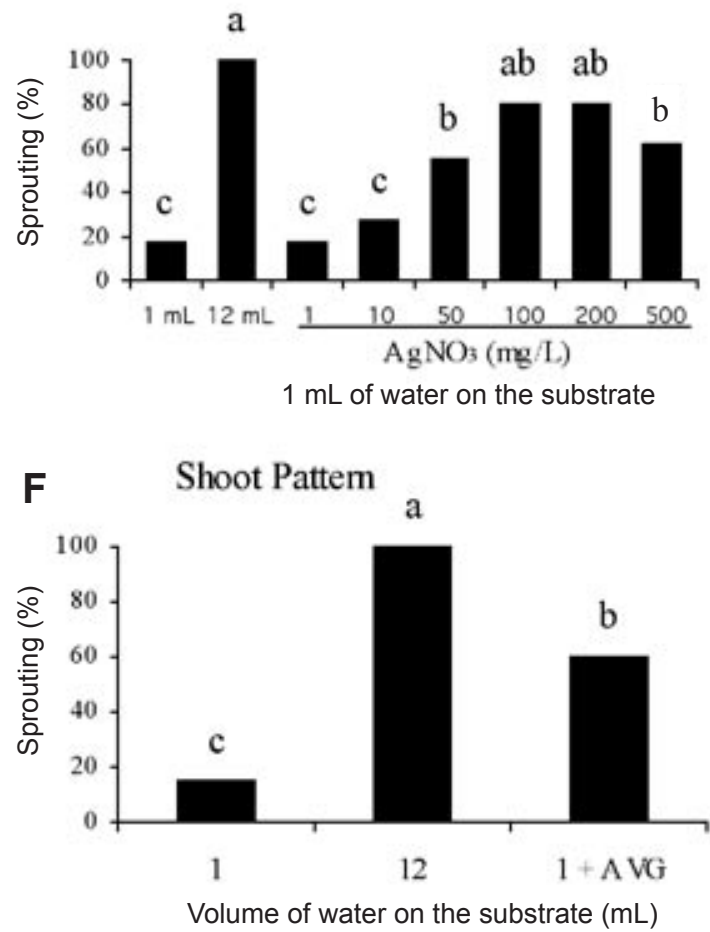

Figura 2. Effect of different substances on the pattern of sprouting development of rhizome sections of $K$. eriantha kept on substrate with 1 and $12 \mathrm{~mL}$ of water under continuous light at $30^{\circ} \mathrm{C}$, on day 20 of the experiment. A,B: $10^{-3} \mathrm{M} \mathrm{Ethrel}(20 \mu \mathrm{L}$, applied every 2 days for 10 days); C,D: $\mathrm{AgNO}_{3}\left(50 \mu \mathrm{L}\right.$, applied once); E,F: $10^{-3} \mathrm{M}$ AVG (15 $\mu \mathrm{L}$ applied on day 1 and 3 of the experiment). Different letters in each figure indicate significant differences by the Tukey test at the $5 \%$ level. 
Production of ethylene was found in sections kept on substrate with either 1 or $12 \mathrm{~mL}$ of water at both time points, however the concentration was higher in sections on substrate with low water availability (figure 4).

A gas chromatograph coupled to a mass spectrometer (GC/MS) was used to characterize the possible involvement of $\mathrm{ABA}$ in the control of development of the rhizome pattern. Acid fractions of extracts from rhizome sections kept on 1 or $12 \mathrm{~mL}$ of water were used. The retention time of methylated cis and trans standard $\mathrm{ABA}$ isomers was determined by means of GC-MS at 26,2 and 27,8 min. Figures 5A, B and C show the characteristic signals of its isomers and their respective mass spectra, with predominance of the ion at $\mathrm{m} / \mathrm{z} 190$. In figures 6 and 7 the ion at m/z 190 is monitored and detected

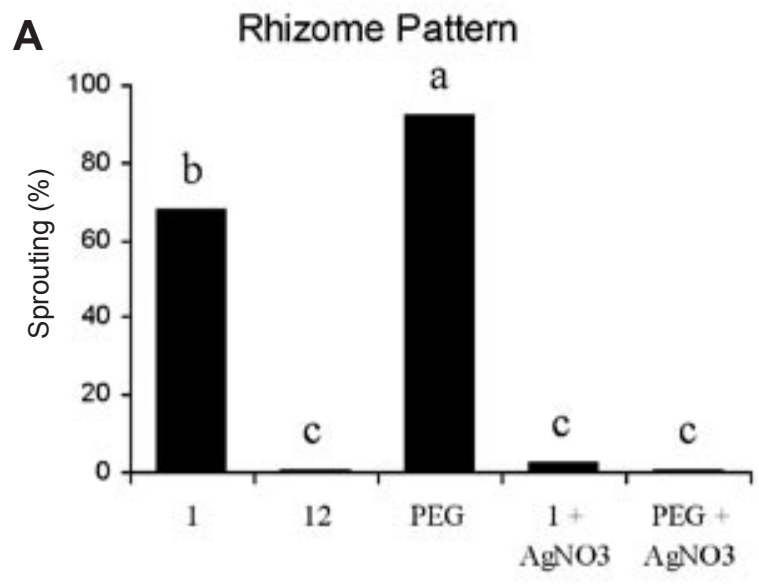

Volume of water on the substrate $(\mathrm{mL})$

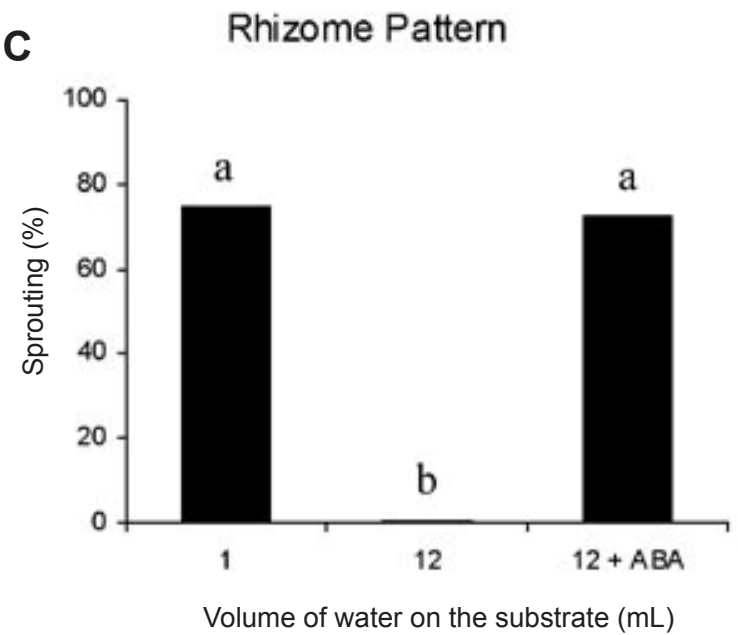

in the chromatogram of the methylated acid fractions of the extracts from sections on substrate with 1 and $12 \mathrm{~mL}$ of water, figures $6 \mathrm{~A}, \mathrm{~B}$ and $\mathrm{C}$ and $7 \mathrm{~A}, \mathrm{~B}$ and $\mathrm{C}$, respectively. Although the ion at $\mathrm{m} / \mathrm{z} 190$ was found in both samples, injection of equal sample volumes $(1 \mu \mathrm{L})$ and use of the same analysis conditions allow us conclude that its abundance was greater in the chromatogram of the acid fraction obtained from sections on substrate with $1 \mathrm{~mL}$ of water than that from sections on $12 \mathrm{~mL}$.

\section{DISCUSSION}

This study points out the ability of ABA and ethylene to influence the morphological development of rhizome buds of $K$. eriantha. The meristem is the site of

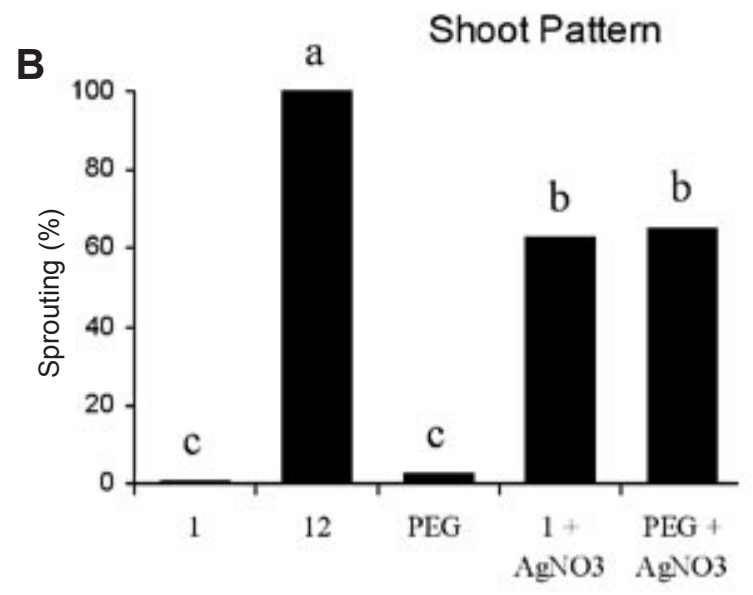

Volume of water on the substrate $(\mathrm{mL})$

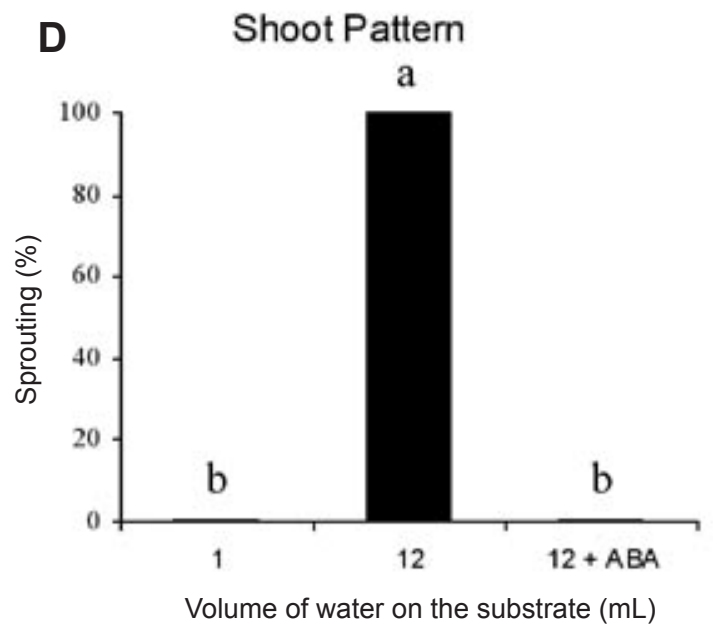

Figura 3. Effect of $\mathrm{AgNO}_{3}\left(500 \mathrm{mg} \cdot \mathrm{L}^{-1}\right)$ used as a droplet $(50 \mu \mathrm{L})(\mathrm{A}, \mathrm{B})$ and $\mathrm{ABA}\left(10^{-3} \mathrm{M}\right)(25 \mu \mathrm{L}$ applied every 2 days for 5 days) (C,D) on the pattern of sprouting development of rhizome sections of $K$. eriantha kept on substrate with $12 \mathrm{~mL}$ of PEG (-6 MPa) solution and $12 \mathrm{~mL}$ of water, respectively, under continuous light at $30^{\circ} \mathrm{C}$, on day 20 of the experiment. Different letters in each figure indicate significant differences by the Tukey test at the $5 \%$ level. 
morphogenetic processes and intense biochemical activity that precedes the morphological alterations, leading to cell division, differentiation and specialization (Cutter, 1986). Determination of the sprouting pattern in K. eriantha was rapid, with the sections attaining a high percentage of sprouting by day 4 of the experiment (Almeida and Pereira,

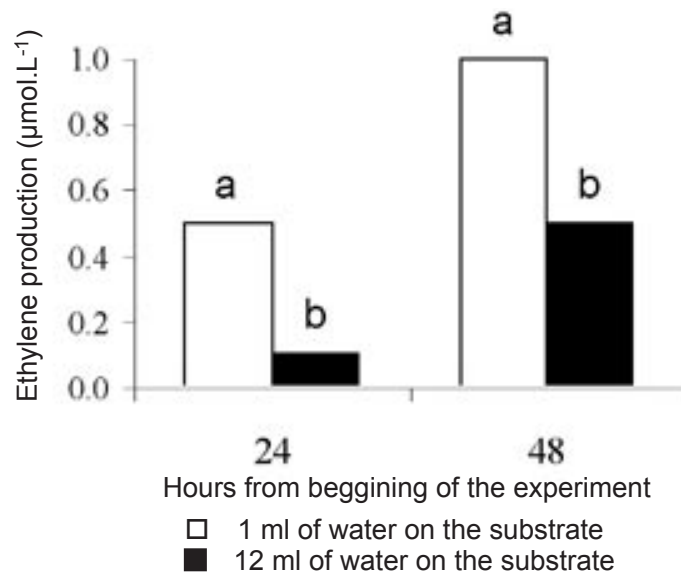

Figura 4. Ethylene released by rhizome sections of $K$. eriantha kept on substrate with 1 and $12 \mathrm{~mL}$ of water under continuous light at $30^{\circ} \mathrm{C}$. Different letters on the observation day indicate significant differences by the Tukey test at the $5 \%$ level.
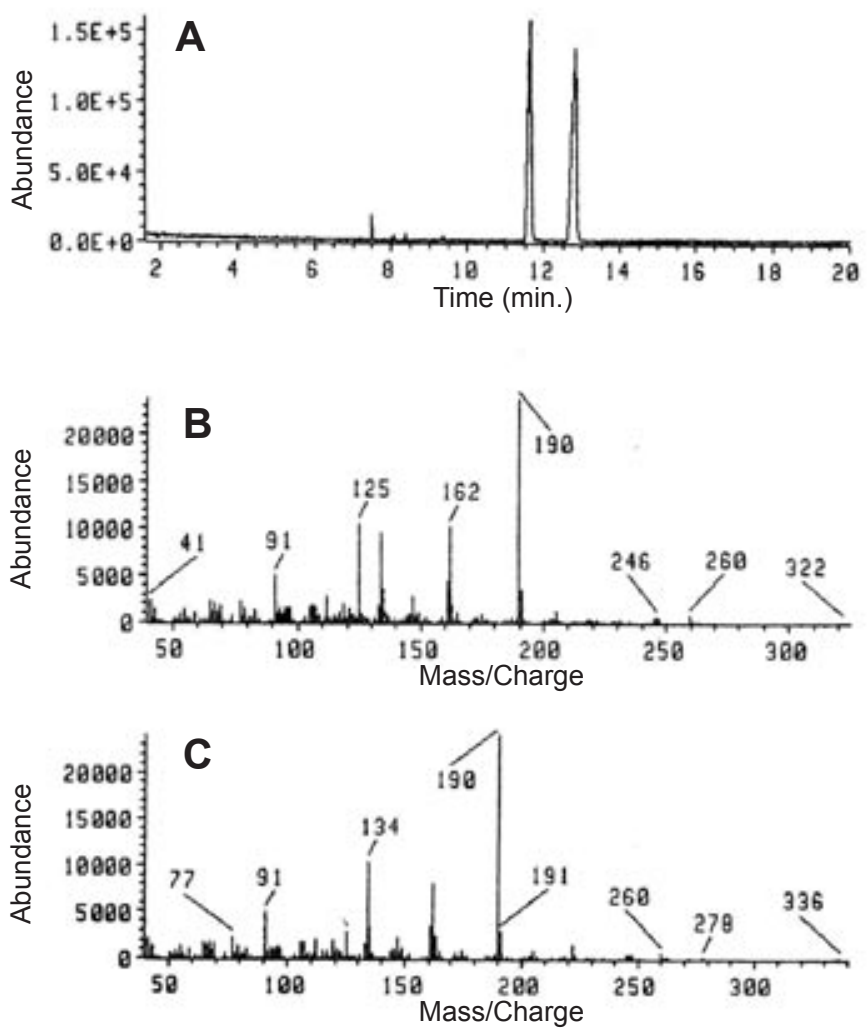

Figure 5. Mass spectrum of standard ABA (A), and mass spectrum of methylated cis- (B) and trans- (C) isomers of standard ABA.
2002), and by day 6 the morphological pattern was visible and defined (data not shown). Thus, the bud meristem of $K$. eriantha quickly showed competence and determination to develop into one of the two sprouting patterns, following its exposure to different environmental conditions.

Rhizome sections of $K$. eriantha also showed resistance to water loss, since they sprouted and developed additional rhizomes even under low water availability $(1 \mathrm{~mL})$. This corroborates observations by Kvist and Skog (1992) that $K$. eriantha rhizomes are resistant to water loss. According to Bewley et al. (1993) plants develop mechanisms to prevent water loss, and many escape drought by virtue of morphological and/or physiological attributes.

Involvement of ethylene and $\mathrm{ABA}$ in the control of development of rhizome pattern in $K$. eriantha under the condition of low water availability $(1 \mathrm{~mL})$ was verified indirectly and directly. Ethrel, a synthetic source of ethylene, induced the development of rhizogenous growth to a level seen under water limiting conditions even in the presence of sufficient water to induce shoot development. Treatment with ethylene inhibitors, $\mathrm{AgNO}_{3}$ and $\mathrm{AVG}$, prevented the occurrence of the rhizogenous growth pattern and induced
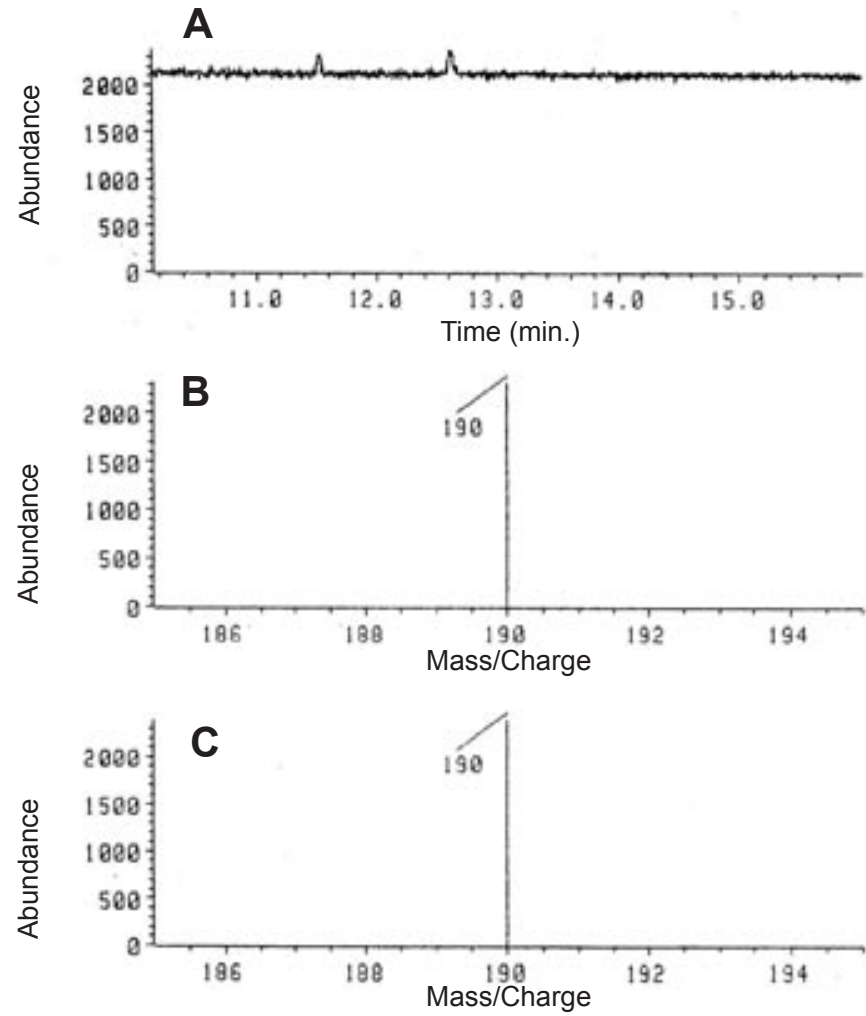

Figure 6. Mass spectrum using the selected ion at m/z 190 of ABA of the extract from rhizome sections kept on substrate with $1 \mathrm{~mL}$ of water (A), and mass spectrum of cis- (B) and trans- ABA $(C)$ isomers found in the extract. 
development of the aerial shoots on substrate with low water availability $(1 \mathrm{~mL})$. Direct involvement of ethylene was shown by an increase in its production on sections grown under low water availability $(1 \mathrm{~mL})$ compared to that observed on sections grown with excess of water $(12 \mathrm{~mL})$. Detection of ethylene production by day two indicates that ethylene may play a direct role in regulating the development of rhizome buds of $K$. eriantha subjected to low water availability of water $(1 \mathrm{~mL})$.

Indirect involvement of ABA was verified by exogenous application of ABA which induced the development of the rhizome pattern even under high water availability and directly by comparisons of ABA levels from sections grown on substrates that induced or inhibited rhizome development. In the analysis, the most abundant components co-purified with the isomer standards of $\mathrm{ABA}$ and thus are likely $\mathrm{ABA}$ derivatives. Ions at $\mathrm{m} / \mathrm{z} 190$ have also been found in the purified extract of ABA from other species, in Zea mays (Rivier et al., 1977), Malus domestica (Subbaiah and Powell, 1987), Citrus sinensis (Cowan and Richardson, 1993) and Larix decidua (Label and Lelu, 1994). In K. eriantha the
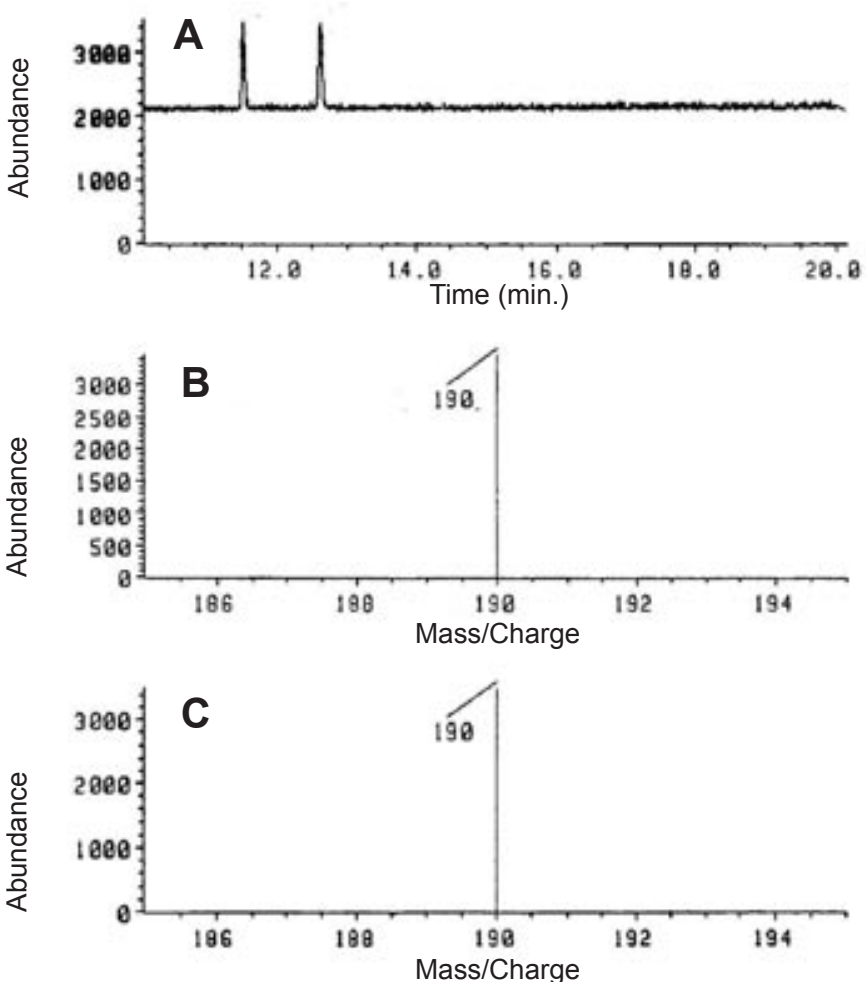

Figure 7. Mass spectrum using the selected ion at $\mathrm{m} / \mathrm{z} 190$ of ABA of the extract from rhizome sections kept on substrate with $12 \mathrm{~mL}$ of water (A), and mass spectrum of cis- (B) and trans-ABA $(C)$ isomers found in the extract. putative $\mathrm{ABA}$ ion at $\mathrm{m} / \mathrm{z} 190$ was more abundant in the sections kept on substrate with low water availability than that from sections with sufficient water. Therefore, this study shows that ABA is also likely to be involved in the control of development of the rhizome pattern of rhizome sections.

From the results obtained with ethylene and ABA, both indirectly and directly, it is suggested that these substances may play a significant role in the control of the developmental pattern of the rhizome sections of $K$. eriantha in response to water availability. Ethylene and ABA may control this process in different ways. Nevertheless, there are studies that indicate that ABA, under water stress, may promote the production of ethylene, as verified in Gossypium hirsutum (Cracker and Abeles, 1969), Phaseolus vulgaris (Jackson and Osborne, 1975), C. sinensis (Goren et al., 1979) and in O. sativa (Yeh et al., 1995). It is suggested, therefore, that this relation may also occur with regard to the rhizome bud development program $K$. eriantha.

Acknowledgments: To Coordenação de Aperfeiçoamento de Pessoal de Nível superior (CAPES) for the financial support.

\section{REFERENCES}

Abeles FB, Morgan PW, Saltveit Jr M (1992) Ethylene in plant biology, 2nd edn. Academic Press, San Diego.

Almeida JAS (1997) Caracterização e brotação do órgão subterrâneo de Kohleria sp. Campinas, Universidade Estadual de Campinas. Doctorate thesis.

Almeida JAS, Pereira, MFDA (2000) Multiplicação vegetativa em plantas de Kohleria sp. Rev. Brás. Hortic. Ornam. 6:47-52.

Almeida JAS, Pereira, MFDA (2002) Brotação do rizoma de Kohleria sp. Braz. J. Plant Physiol. 14:45-50.

Almeida JAS, Pereira, MFDA (2004) Efeito da temperatura e do teor de umidade na iniciação e desenvolvimento do rizoma de Kohleria eriantha (Benth.) Hanst. (Gesneriaceae). Acta Bot. Bras. 18:863-869.

Annonymous (1991) GRF Seminar series: The biology of Kohleria. Gesneriad Research Foundation.

Apelbaum A, Yang SF (1981) Biosynthesis of stress ethylene induced by water deficit. Plant Physiol. 68:594-596.

Arteca RN, Bachman JM, Mandava NB (1988) Effects of indole-3-acetic and brassinosteroid on ethylene biosynthesis in etiolated mung bean hypocotyl segments. J. Plant Physiol. 133:430-435.

Barros RS, Neill SJ (1987) Shoot growth in willow (Salix viminalis) in relation to abscisic acid, plant water status and photoperiod. Physiol. Plant. 70:708-712.

Bartels D, Schneider K, Terstappen G, Piatkowski D, Salamini F (1990) Molecular cloning of abscisic acid modu- 
lated genes which are induced during desiccation of the resurrection plant Craterostigma plantagineum. Planta 181:27-34.

Ben-Yehoshua S, Aloni B (1974) Effect of water stress on ethylene production by detached leaves of Valencia orange (Citrus sinensis Osbeck). Plant Physiol. 53:863-865.

Bewley JD, Reynolds TL, Oliver MJ (1993) Involving strategies in the adaptation to desiccation. In: Timothy JC, Bray EA (eds), Plant responses to cellular dehydration during environmental stress, pp.193-201. The American Society of Plant Physiologists.

Blumenfeld A (1975) Ethylene and Annona flower. Plant Physiol. 55:265-269.

Bradford KJ, Yang SF (1980) Stress-induced ethylene production in the ethylene-requiring tomato mutant diageotropica. Plant Physiol. 65:327-330.

Chopra RN, Kapur A (1988) Effect of abscisic acid and kinetin on protonemal differentiation in Timmiella anomala. Plant Sci. 61:203-206.

Cowan AK, Richardson GR (1993) The biosynthesis of abscisic acid from all- $\beta$-carotene in a cell-free system from Citrus sinensis exocarp. Plant Cell Physiol. 34:969-972.

Cracker LE, Abeles FB (1969) Abscission: role of abscisic acid. Plant Physiol. 44:1144-1149.

Creelman RA, Wason HS, Bensen RJ, Boyer JS, Mullet JE 1990 Water deficit and abscisic acid cause differential inhibition of shoot versus root growth in soybean seedlings. Plant Physiol. 92:205-214.

Cutter EG (1986) Anatomia vegetal. $2^{a}$ Edição, Livraria Roca Ltda, São Paulo, 304p.

Goren R, Altman A, Giladi I (1979) Role of ethylene in abscisic acid-induced callus formation in citrus bud cultures. Plant Physiol. 63:280-282.

Grossmann K, Kwiatrowski J (1993a) Selective induction of ethylene and cyanide biosynthesis appears to be involved in the selectivity of herbicide quinclorac between rice and barnyardgrass. J. Plant Physiol. 142:457-466.

Grossmann K, Siefert F, Kwiatkoswski J, Schraudner M, Langeebartels C, Sandermann Jr H (1993b) Inhibition of ethylene production in sunflower cell suspensions by the plant growth retardant BAS 111.W: possible relations to changes in polyamine and cytokinin contents. J. Plant Growth Regul. 12:5-11.

Hale MG, Orcutt DM (1987) The physiology of plants under stress. Wiley, Interscience.

Hoson T, Maeda S, Sakaguchi K, Onshi H, Ohta H (1990) Changes in osmotic pressure and cell wall properties during auxin and ethylene induced growth of intact coleoptiles of rice. Physiol. Plant. 78:277-284.

Hyodo H (1991) Stress/wound ethylene. In: Mattoo AK, Suttle JC (eds), The plant hormone ethylene, pp.43-63. CRC Press, London.

Jackson MB, Osborne DJ (1975) Abscisic acid, auxin and ethylene in explant abscission. J. Exp. Bot 23:849-862.
Jensen E, Crozier A, Monteiro AM (1986) Analysis of gibberellin conjugates by ion-supression reversed-phase high-performace liquid chromatography. J. Chromatogr. 367:377-384.

Kapuya JA, Hall MA (1984) Plant sensitivity to endogenous ethylene in relation to species characteristics. Z. Pflanzanphysiol. 113:461-464.

Kim WT, Silverstone A, Yip WK, Dong JG, Yang SF (1992) Induction of 1-aminocyclopropane-1-carboxylate synthase mRNA by auxin in mung bean hypocotyls and cultured apple shoots. Plant Physiol. 98:465-471.

Kvist LP, Skog LE (1992) Revision of Kohleria (Gesneriaceae). Smithsonian Institution Press, Washington.

Label P, Lelu MA (1994) Influence of exogenous abscisic acid on germination and plantlet conversion frequencies of hybrid larch somatic embryos (Larix X leptoeuropaea). Plant Growth Regul. 15:175-182.

Leone A, Costa A, Tucci M, Grillo S (1994) Adaptation versus shock response to polyethylene glycol-induced low water potential in cultured potato cells. Physiol. Plant. 92:21-30.

Lopez-Carbonell M, Alegre L, van Onckelen H (1994) Changes in cell ultrastructure and endogenous abscisic acid and indole-3-acetic acid concentrations in Fatsia japonica leaves under polyethylene glycol induced water stress. Plant Growth Regul. 15:165-174.

Mattoo KJ, White BW (1991) Regulation of ethylene-synthetisizing system in apple tissue. Plant Physiol. 18:715-719.

Michel BE, Kaufman MR (1973) The osmotic potential of polyethylene glicol 6000. Plant Physiol. 51:914-916.

Neill SJ, Horgan R (1984) Biosynthesis of abscisic acid. In: Crozier A, Hillman JR (eds), The biosynthesis of plant hormones, pp.43-70. Cambridge University Press, England.

Pimentel GF (1984) A estatística moderna na pesquisa agropecuária. Associação Brasileira de Pesquisa Potassa e do Fosfato, Piracicaba.

Rivier L, Milon H, Pilet P-E (1977) Gas chromatography-mass spectrometric determinations of abscisic acid levels in the cap and the apex of maize roots. Planta 134:23-27.

Rothan C, Nicolas J (1994) High CO $\mathrm{CO}_{2}$ levels reduce ethylene production in kiwifruit. Physiol. Plant. 92:1-8.

Saftner RA (1992) Effects of turgor potential on 1-aminocyclopropane-1-carboxylic acid uptake into the vacuolar compartment and ethylene production in tomato pericarp slices. Physiol. Plant. 85:157-166.

Sarquis JI, Morgan PW, Jordan WR (1992) Metabollism of 1-aminocyclopropane-1-carboxylic acid in etiolated maize seedlings grown under mechanical impedance. Plant Physiol. 98:1342-1348.

Saunders PF (1978) The identification and quantitative analysis of abscisic acid in plant extracts. In: Hillman JR (ed), Isolation of plant growth substances, pp.115-134. Cambridge University Press, London.

Schenk H, Gellerman JL (1960) Esterification of fatty acids with diazomethane on a small scale. Anal. Chem. 32: 1412-1414. 
Smart CC, Fleming AJ, Hanke DE (1995) The physiological role of abscisic acid in eliciting turion morphogenesis. Plant Physiol. 108: 623-632.

Smulders MJM, Kemp A, Barendse GWM, Croes AF, Wullems GJ (1990) Role of ethylene in auxin-induced flower bud formation in tobacco explants. Physiol. Plant. 78: 167-172.

Subbaiah T, Powell L (1987) Abscisic acid in dormant apple seed tissues - a rapid purification scheme using prepacked columns and GCMS-SIM quantitation. Physiol. Plant. 71:203-206.

Tan Z, Thimann KV (1989) The roles of carbon dioxide and abscisic acid in the production of ethylene. Physiol. Plant. 75:13-19.

Trewavas A (1981) How do plant growth substances work? Plant Cell Environ. 4:203-228.

Vreugdenhil D, van Dijk W (1989a) Effects of ethylene on tuberization in radish (Raphanus sativus). Plant Growth Regul. 8:21-30.

Vreugdenhil D, van Dijk W (1989b) Effects of ethylene on the tuberization of potato (Solanum tuberosum) cuttings. Plant Growth Regul. 8:31-39.
Werner O, Espín RMR, Bopp M, Atzorn R (1991) Abscisicacid-induced drought tolerance in Funaria hygrometrica Hedw. Planta 186:99-103.

Yang SF 1987 Regulation of biosynthesis and action of ethylene. Acta Hortic. 201:53-59.

Yang SF, Hoffman NE (1984) Ethylene biosynthesis and its regulation in higher plants. Ann. Rev. Plant Physiol. 35: 155-89.

Yeang HY, Hillman JR (1982) Lateral bud growth in Phaseolus vulgaris $\mathrm{L}$. and the levels of ethylene in the bud and adjacent tissue. J. Exp. Bot 132:111-117.

Yeh CC, Tsay H-S, Yeh JH, Tsai FY, Shih CY, Kao CH (1995) A comparative study of the effects of methyl jasmonate and abscisic acid on some rice physiological process. J. Plant Growth Regul. 14:23-28.

Yoshii H, Imaseki H (1981) Biosynthesis of auxin-induced ethylene. Effects of indole-3-acetic acid, benzyladenine and abscisic acid on endogenous levels of 1-aminocyclopropane-1-carboxylic acid (ACC) and ACC synthase. Plant Cell Physiol. 22:369-379.

Yu Y, Yang SF (1980) Biosynthesis of wound ethylene. Plant Physiol. 66:281-285.

Zhang J, Davies WJ (1987) ABA in roots and leaves of flooded pea plants. J. Exp. Bot. 38:649-659. 